\section{The tobacco industry's deadly distortions of history}

\author{
Louis M Kyriakoudes
}

The manipulation of history has been a key strategy in the tobacco industry's long campaign to promote its products in the marketplace and to defend itself in civil litigation. I first wrote about the tobacco industry's use of professional historians as expert witnesses in US courts in this journal in $2006 .^{1}$ In that study, I explored how historians retained by the industry's legal defence testified that the public had long known that cigarettes caused addiction and deadly disease. To support this misleading testimony, industry historians developed idiosyncratic, indeed absurd, concepts of 'common knowledge' and 'public awareness' to claim that the prevalence of antitobacco news coverage indicated public understanding that cigarette use caused disease, disability and death. Industry-retained historians bolstered their conclusions in court with highly selective presentations of historical evidence from newspapers, magazines and other public sources reporting on the connections between smoking and disease. To historians defending Big Tobacco, the industry's own disinformation campaign to discredit the public health community had no historical impact whatsoever. Cigarette advertising and the extensive evidence in the tobacco industry's internal files measuring smoker ignorance of the health dangers of cigarettes were of no interest to

Correspondence to Dr Louis M Kyriakoudes, Albert Gore Research Center, Middle Tennessee State University, P.O. Box 193, 1301 E. Main Street, Murfreesboro, TN 37132, USA; Louis.Kyriakoudes@ mtsu.edu these historians. I concluded that the flawed methodology employed by these scholars resulted in a profoundly misleading analysis in which the tobacco industry, the most important agent in the rise of the cigarette, had been written out of history.

Cynthia Callard's study in this edition of Tobacco Control extends this line of inquiry by looking at the use of historians in Canadian tobacco litigation. Callard applies the tools of content analysis to systematically examine a data set of historical media materials produced by tobacco industry experts to support their opinion that the risk of cigarette use was widely known in Quebec. Callard's analysis of the industry's own defence materials tells a story that directly contradicts that of the tobacco industry's experts. Callard finds that up through the mid 1980s, prosmoking messages prevailed over antismoking messages. This is an important finding that reminds the tobacco control community that the industry, with its language of uncertain science and smoking as a choice, successfully controlled the narrative over smoking and health until very recent times-and to an extent continues to do so even to this day.

The tobacco industry has long understood the importance of shaping historical knowledge about its products. In the $1950 \mathrm{~s}$ and 1960s the Tobacco Institute sponsored histories that celebrated the rise of the cigarette in American life. ${ }^{2}$ In the 1980s, Philip Morris underwrote the costs of the national bicentennial tour of one of the original parchment copies of the Bill of Rights, drawing directly the connections between American's core political freedoms and the 'freedom' to smoke cigarettes. ${ }^{3}$ And as Callard's study shows, the industry still employs historians to whitewash the history of the tobacco industry in the courtroom. Our understanding of the past shapes our future. As the industry brings new tobacco and nicotine products to market in its efforts to ensnare yet another generation of young people, the tobacco control movement must continue to insist on an accurate understanding of the industry's history.

Competing interests LMK is a historian who has served as an expert witness for plaintiffs in tobacco litigation against US cigarette manufactures.

Provenance and peer review Commissioned; internally peer reviewed.

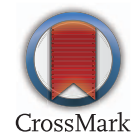

To cite Kyriakoudes LM. Tob Control 2016;25:491.

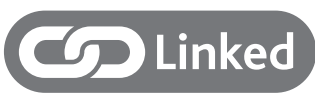

http://dx.doi.org/10.1136/tobaccocontrol-2015052618

Tob Control 2016;25:491.

doi:10.1136/tobaccocontrol-2015-052712

\section{REFERENCES}

1 Kyriakoudes LM. Historians' testimony on "common knowledge" of the risks of tobacco use: a review and analysis of experts testifying on behalf of cigarette manufacturers in civil litigation. Tob Control 2006;15 (Suppl 4):iv107-16.

2 Hill \& Knowlton. Book: Tobacco and Americans. 5 February 1960. Philip Morris. https://www. industrydocumentslibrary.ucsf.edu/tobacco/docs/gsgw0130

3 National Archives and Record Administration. Press Release: 200th anniversary of the Bill of Rights. 1989 November 01. Tobacco Institute; Roswell Park Cancer Institute (RPCI). https://www.industrydocumentslibrary. ucsf.edu/tobacco/docs/nlpp0046 